\title{
Gender Wise Return Migration Decision and Migrant's Perception towards Developmental Impact in Place of Origin-An Empirical Study
}

\author{
B. C. M. Patnak ${ }^{1}$, Ipseeta Satpathy ${ }^{1} \&$ Anirban Mndal $^{1}$ \\ ${ }^{1}$ School of Management, KIIT University, Bhubaneswar, India \\ Correspondence: B. C. M. Patnaik, School of Management, KIIT University, Bhubaneshwar, Odisha, India. Te: \\ 91-966-822-4322. E-mail: bcmpatnaik@gmil.com
}

Received: December 28, 2014 Accepted: March 17, 2015 Online Published: May 14, 2015

doi:10.5539/res.v7n7p158 URL: http://dx.doi.org/10.5539/res.v7n7p158

\begin{abstract}
Return migration is a concept where migrants returned back to their respective place of origin after working for a specific period of time to earn enough money to start their own income generating opportunities with the help of it. This often sees as a movement which creates tremendous positive impact in migrant's own places as they not only brings capital with them, along with it they also brings expertise, resource and technology which helps to improve the livelihood of those people who failed to migrate because of poor socio economic conditions. The present study aimed to discuss the perception of returns migrants and its developmental impact on the place of origin.
\end{abstract}

Keywords: return migration, skill development, place of origin, development impact, ideal score, least score

\section{Introduction}

Migration is a process which people often take to maintain their livelihood when they fail to earn sufficiently in their own place. This is sometimes an individual's decision or sometimes it depends on the need of the family members (Sanchez, 1998). People generally move from an area where developmental outcome has low impact and subsequent growth prospect is also low to an area where economic growth is higher. This high growth rate creates new job opportunities and alternative earning opportunities for those who live in backward regions of an area (Wiesbrock, 2008). Thus, we can say that the main reason for movement is due to unequal growth of various areas.

Although people are moving for earning purposes, but duration of stay may vary. It is basically depends on the nature of the job, financial requirement of the migrants and most importantly migrant's own decision regarding duration of stay. Normally, it is found that if the job is permanent in nature, then people also move permanently from one place to another. But this type of movement is mainly restricted to people who have certain levels of skill which help them to find jobs in formal sectors (Christophe, 2008). Level of education is also another important criterion in this regard. But apart from this most of the movement is normally temporary in nature where migrants may move on seasonal basis during a specific period of a year or may move for a specific period of time where the only objective is to earn sufficiently so that when they returned back permanently, they should have sufficient earnings in their own hand to start their own income generating opportunities (Upadhya, 2012). These groups are termed as return migrants. Normally, their impact in place of origin is valuable, as they not only brings capital, they also brings various income generating opportunities as well as knowledge and expertise. This helps other to engage in other income generating opportunities apart from agriculture. Remittances are another important angle which helps to bring new technologies in the place of origin which ultimately improve the economic condition of the place of origin (Jokish, 2014) and if this movement is of international in nature then along with technology and expertise it also helps the country to earn foreign exchange which any developing country is looking for. But this positive benefit basically depends on migrant's decision to contribute in terms of knowledge, money as well as technology; which subsequently depends on specific socio economic conditions of the place of origin. On the other hand we can say that if the support infrastructure is not there then the expected benefit may not be achieved (Hanna, 2010). The issue of social network is also important in this kind of movement. It is observed that since most of the migrants are engage themselves in informal sectors, the 
social networks play a very active role in getting a job in urban location (Haug, 2010). But there is a doubt whether migrants who are engage in informal sectors is in a position to contribute positively towards local area improvement. Because, return migration of skilled workforce will only be effective for sending country, receiving country and the individuals, if adequate policies and environment created for the same (Anja, 2008).

\section{Materials \& Methods}

\subsection{Research Objective}

Decision to migrate has lots of significance in both place of origin as well as place of destination. But the consequence of this decision may vary depending on the nature of migration and kind of benefits migrants able to bring in their respective places. The present study would like to focus on the below mentioned objective:

- Gender wise migrant's perception that decision of return migration brings positive development in their place of origin

\subsection{Reliability \& Validity Test of the Study Questionnaire}

The Malda district of West Bengal, India, is a migration prone district and around $90 \%$ of the state's total migration is happening from this district only. This gives us an ideal choice of Malda district as the study district for the present study.

For the purpose of collection of data initially a pilot study has been conducted to identify the research variables and subsequently to test the reliability and validity of the research questionnaire. Initially 13 variables are identified which subsequently reduced to six only after conducting the validity test. A Likert type questionnaire has been designed to get the relevant information about migrant's perception towards return migration and its developmental impact on place of origin.

During pilot study 54 respondents have been identified to test the reliability of the questionnaire. For this purpose Cronbach's alpha technique is considered which says that if the "alpha" value is more than 0.70 , then we can conclude that the questionnaire is reliable for further study. The result of the value is shown in the table below:

Table 1. Reliability statistics

\begin{tabular}{cc}
\hline Cronbach's Alpha & N of Items \\
\hline .840 & 13 \\
\hline
\end{tabular}

Source: Survey data.

The "alpha" value 0.84 for the present study shows that the questionnaire that has been developed can be utilize for further study. But only reliability test doesn't give us adequate information in this regard. Thus, along this we have to check the validity of the questionnaire, which has been tested using Principal Component Analysis (PCA), using varimax principle. This technique helps us to retain 6 variables for the final research and the research questionnaire has been modified accordingly.

To conduct a PCA two tests need to be satisfied; i.e. KMO Measure of sampling adequacy should be $>0.70$ and Bartlett's Test of Sphercity should be significant (less than 0.05). In the present case both the conditions are satisfied and thus we can go ahead with PCA technique. The result is shown in the table below:

Table 2. KMO and bartlett's test

\begin{tabular}{lll}
\hline Kaiser-Meyer-Olkin Measure of Sampling Adequacy. & .781 \\
\hline \multirow{3}{*}{ Bartlett's Test of Sphericity } & Approx. Chi-Square & 275.702 \\
& Df & 15 \\
& Sig. & .000 \\
\hline
\end{tabular}

As mentioned above, this particular technique helps us to retain 6 variables out of 13 variables because these 6 variables have high loading corresponding to their factors. The six retained variables are listed in the table below: 
Table 3. List of final variables

\begin{tabular}{|c|c|c|c|}
\hline Variables & Factor 1 & Factor 2 & Communalities \\
\hline $\begin{array}{l}\text { Variable 1: Return Migrants bring knowledge about various income } \\
\text { generating activities in the place of origin }\end{array}$ & & 0.870 & 0.757 \\
\hline $\begin{array}{l}\text { Variable 2: Return Migrants bring capital which help in generating } \\
\text { alternative source of income in the place of origin }\end{array}$ & & 0.693 & 0.584 \\
\hline $\begin{array}{l}\text { Variable 3: Return Migrants bring innovative working environment } \\
\text { which can be use for more productive purposes in the place of origin }\end{array}$ & & 0.487 & 0.452 \\
\hline $\begin{array}{l}\text { Variable 4: Return Migrants bring work opportunities for those who } \\
\text { failed to migrate because of high cost of living and high cost of } \\
\text { movement }\end{array}$ & 0.646 & & 0.464 \\
\hline $\begin{array}{l}\text { Variable 5: Return Migrants help to improve living condition of the } \\
\text { people in the place of origin }\end{array}$ & 0.760 & & 0.632 \\
\hline $\begin{array}{l}\text { Variable 6: Return Migrants help to improve life style of the people in } \\
\text { the place of origin }\end{array}$ & 0.814 & & 0.663 \\
\hline Variance Explained & 32.928 & 26.296 & \\
\hline Total Variance Explained & 59.224 & & \\
\hline
\end{tabular}

\subsection{Sampling Plan}

As it is very difficult to get a structured data related to return migration, the authors decided to opt for convenience sampling technique to get adequate representation of the population. The data has been collected with the help of structured questionnaire after incorporating necessary changes and in total 500 questionnaires were distributed to collect the relevant information from the study district. At the end of the survey total 258 questionnaires were received in correct form incorporated in the final research. Thus the response rate was 52\%.

The Likert scale has been categorized as "Strongly Agree", "Agree", "Neutral", "Disagree" and "Strongly Disagree" to capture the responses of the respondents with corresponding weight as "5", "4", "3", "2" and "1" respectively for each category. To judge the responses an ideal score and least score has been developed in the following manner:

Ideal Score: Ideal Scores are calculated by multiplying the number of respondents in each category with 5 (highest score) and product with total number of variables.

Least Score: The least Scores are calculated by multiplying the number of respondents in each category with 1 (least score) and product with total number of variables.

The calculation is shown in the table below:

In the present research out of total 258 respondents 149 respondents are male and 109 respondents are female.

Table 4. Ideal and least scores

\begin{tabular}{lllll}
\hline Category & Equation & Ideal Score & Equation & Least Score \\
\hline $\begin{array}{l}\text { Male Return } \\
\text { Migrants (149) }\end{array}$ & $149 \times 5 \times 6$ & 4470 & $149 \times 1 \times 6$ & 894 \\
$\begin{array}{l}\text { Female Return } \\
\text { Migrants (109) }\end{array}$ & $109 \times 5 \times 6$ & 3270 & $109 \times 1 \times 6$ & 654 \\
\hline
\end{tabular}

\section{Analysis of Data}

The table below indicates male group wise return migrant's perception about the positive impact that they can bring in place of origin if they decided to return. 
Table 5. Male group wise perception

Variable

Perception of Male Return Migrants

\begin{tabular}{|c|c|c|c|c|c|c|}
\hline \multirow[t]{2}{*}{ vallavie } & SA & A & $\mathbf{N}$ & DA & SDA & \multirow{2}{*}{$\begin{array}{l}\text { Total } \\
\text { Score }\end{array}$} \\
\hline & 5 & 4 & 3 & 2 & 1 & \\
\hline
\end{tabular}
generating activities in the place of origin

Variable 2: Return Migrants bring capital which help in generating $\begin{array}{llllllll}78 & 66 & 2 & 2 & 1 & 665\end{array}$ alternative source of income in the place of origin

$\begin{array}{llllllll}\text { Variable 3: Return Migrants bring innovative working environment } & 82 & 60 & 4 & 3 & 0 & 668\end{array}$ which can be use for more productive purposes in the place of origin

Variable 4: Return Migrants bring work opportunities for those who failed to migrate because of high cost of living and high cost of movement

Variable 5: Return Migrants help to improve living condition of the $\begin{array}{lllllll}102 & 41 & 5 & 1 & 0 & 691\end{array}$ people in the place of origin

Variable 6: Return Migrants help to improve life style of the people $\begin{array}{lllllll}76 & 68 & 0 & 4 & 1 & 661\end{array}$ in the place of origin

Source: Survey data.

The table clearly shows that only in case of variable 1 , the male return migrants are strongly disagree or disagree with the statement. This may be the case that as most of them are engaged in informal sectors after migration they do not have much variety in terms of exposure to various types of jobs in nearest urban location. But for rest of the variables they are either strongly agree or agree with the statement as most of them earn sufficient money during migration process which helps them to start their own income generating opportunities in place of origin. This not only brings capital it also creates income generating opportunities for others.

But the situation is not same when we look at the perception of the female return migrants. The table below indicates the perception of the female migrants in this regard.

Table 6. Female group wise perception

\begin{tabular}{|c|c|c|c|c|c|c|}
\hline \multirow{3}{*}{ Variable } & \multicolumn{6}{|c|}{ Perception of Female Return Migrants } \\
\hline & \multirow{2}{*}{$\begin{array}{l}\text { SA } \\
5\end{array}$} & \multirow{2}{*}{$\begin{array}{l}\mathbf{A} \\
4\end{array}$} & \multirow{2}{*}{$\begin{array}{l}\mathbf{N} \\
\mathbf{3}\end{array}$} & \multirow{2}{*}{$\begin{array}{l}\text { DA } \\
2\end{array}$} & \multirow{2}{*}{$\begin{array}{l}\text { SDA } \\
1\end{array}$} & \multirow{2}{*}{$\begin{array}{l}\text { Total } \\
\text { Score }\end{array}$} \\
\hline & & & & & & \\
\hline $\begin{array}{l}\text { Variable 1: Return Migrants bring knowledge about various income } \\
\text { generating activities in the place of origin }\end{array}$ & 0 & 9 & 11 & 49 & 40 & 207 \\
\hline $\begin{array}{l}\text { Variable 2: Return Migrants bring capital which help in generating } \\
\text { alternative source of income in the place of origin }\end{array}$ & 1 & 13 & 3 & 58 & 34 & 216 \\
\hline $\begin{array}{l}\text { Variable 3: Return Migrants bring innovative working environment } \\
\text { which can be use for more productive purposes in the place of origin }\end{array}$ & 2 & 14 & 1 & 47 & 45 & 208 \\
\hline $\begin{array}{l}\text { Variable 4: Return Migrants bring work opportunities for those who } \\
\text { failed to migrate because of high cost of living and high cost of } \\
\text { movement }\end{array}$ & 0 & 12 & 9 & 37 & 51 & 200 \\
\hline $\begin{array}{l}\text { Variable 5: Return Migrants help to improve living condition of the } \\
\text { people in the place of origin }\end{array}$ & 12 & 2 & 10 & 15 & 70 & 198 \\
\hline $\begin{array}{l}\text { Variable 6: Return Migrants help to improve life style of the people in } \\
\text { the place of origin }\end{array}$ & 7 & 3 & 39 & 12 & 48 & 236 \\
\hline
\end{tabular}

Source: Survey data. 
The response captured in Likert scale, shows that most of the female return migrants are either strongly disagree or disagree with the statements. This is a typical socio economic influence that Indian women are facing in this regard. In the study regions, as most of the income generating decision are taken by male members of the household, the women members hardly have any role in this regard. Simply they are migrating because the head of the household are moving and they are returning back as per wish of the male member. Even if they are earning during migration, that income directly goes into the hand of the male members. Thus, women members are not enjoying any kind of financial freedom, which ultimately reflects in their response during the study.

To get a clear idea about gender wise overall perception regarding this we have developed a aggregate score in this regard using ideal score and least score technique. The result is shown in the table below:

Table 7. Gender wise aggregate score of return migrant's perception

\begin{tabular}{lll}
\hline & \multicolumn{2}{l}{ Aggregate Score } \\
\cline { 2 - 3 } Variables & $\begin{array}{l}\text { Male Return } \\
\text { Migrants }\end{array}$ & $\begin{array}{l}\text { Female Return } \\
\text { Migrants }\end{array}$ \\
\hline $\begin{array}{l}\text { Variable 1: Return Migrants bring knowledge about various income } \\
\text { generating activities in the place of origin }\end{array}$ & 315 & 207 \\
$\begin{array}{l}\text { Variable 2: Return Migrants bring capital which help in generating } \\
\text { alternative source of income in the place of origin }\end{array}$ & 665 & 216 \\
$\begin{array}{l}\text { Variable 3: Return Migrants bring innovative working environment which } \\
\text { can be use for more productive purposes in the place of origin }\end{array}$ & 668 \\
$\begin{array}{l}\text { Variable 4: Return Migrants bring work opportunities for those who failed } \\
\text { to migrate because of high cost of living and high cost of movement }\end{array}$ & 692 \\
$\begin{array}{l}\text { Variable 5: Return Migrants help to improve living condition of the people } \\
\text { in the place of origin }\end{array}$ & 691 & 208 \\
$\begin{array}{l}\text { Variable 6: Return Migrants help to improve life style of the people in the } \\
\text { place of origin }\end{array}$ & 661 & 198 \\
$\begin{array}{l}\text { Total Scores } \\
\text { Ideal Scores }\end{array}$ & 3692 & 236 \\
$\begin{array}{l}\text { Least Scores } \\
\text { \%o of Total Score to Ideal Score }\end{array}$ & 4470 & 3270 \\
No. of Respondents & 894 & 654 \\
\hline
\end{tabular}

Source: Computed from table $5 \& 6$.

The table shows that for both the segments total score is not near to least score. But interestingly, there is a huge difference in terms gender wise perception towards, return migrant's perception towards positive impact on place of origin due to their return decision. In case of male return migrants, the percentage of total score to ideal score is approximately $83 \%$, whereas for female migrants the same score is about $39 \%$. This difference shows that it is male return migrants who support the variables but the female migrants don't support the same.

\section{Conclusion}

The study tries to capitalize the consequences of return migration in the study district. Over the years it is noticed that if migration continues then it not only creates a manpower shortage in the place of origin, but also simultaneously going to create a tremendous pressure on the destination area in the form of increasing urbanization. In a developing country like India, where there are mismatches existing in terms of labour demand and supply, this kind of movement needs to be restricted so that both the areas can get adequate benefit for the same. But in this regard, the more important aspect is whether the migrants are willing to return to their respective places or not. This problem can be resolved if the government is able to provide urban opportunities in the rural areas for which the migrants are moving from one place to other. But this is not an easy task, as it requires huge infrastructure investment in those areas where it is lacking so that the migrants can get adequate opportunities in their own places. Having said that, it is equally important to judge the perception of the migrants 
in this regard, which for this study is positive at least for the male migrant members. So, along with that required investment mechanism it is also important to empower women segment, living in a male dominated society. If both these conditions fulfilled then the so called developmental outcome of return migration can be achieved.

\section{References}

Anja, W. (2008). Return Migration as a tool for Economic Development in China and India. IMDS Working Paper, 3.

Brad, D. J. (2014, November). Ecuador: From Mass Immigration to Return Migration? Migration Information Source, Migration Policy Institute.

Carol, U., \& Mario, R. (2012, May). Migration, Transnational Flows \& Development in India: A Regional Perspective. Economic \& Political Weekly, XLVII(19), 54-62.

Gaurav, T. (2012, February). Migration: Impact \& Relevance of Remittance on Rural Areas. Kurukshatra, Journal on Rural Development, 60(4), 16-19.

Gabriel, S. (1998, August). Increasing Political Returns \& Rural Urban Migration Department of Economics \& Business (pp. 1-37). Universitat Pompeu Fabra.

Hanna et al. (2010). Existing Policies and Practices of Reintegration: Case Studies of Return Migration in Bulgaria, Cameroon and Poland. A Project Report Prepared for the Funding Agency. The German Marshall Fund of the US.

Jean, C. D., \& Gilles, S. (2008). Return Migration: A New Perspective. In International Migration Outlook (SOPEMI-2008 ed.). OECD.

Sonja, H. (2010). Migration and Return Migration: The Case of Italian Migrants in Germany. Paper presented to the workshop Labour Migration and Transnationalism in Europe.

UN Chronicle. (2013, September). China's Return Migration and Its Impact on Home Development, L(3).

\section{Copyrights}

Copyright for this article is retained by the author(s), with first publication rights granted to the journal.

This is an open-access article distributed under the terms and conditions of the Creative Commons Attribution license (http://creativecommons.org/licenses/by/3.0/). 